\title{
$\widehat{A}$ Madridge \\ madridge Journal of Pharmaceutical Research \\ interconnecting Scientific World
}

Research Article

Open Access

\section{Health Status of Students in a Private University in Malaysia}

\author{
Sunil K Prajapati*, Abdul Nazer Ali, M Z Iqbal, K Mohanananaidu, Lee Lye Mei and Chew Ningzee \\ Faculty of Pharmacy, AIMST University, Malaysia
}

\section{Article Info}

*Corresponding author:
Sunil K Prajapati
Faculty of Pharmacy
AIMST University
Semeling, 08100
Bedong
Kedah Darul Aman
Malaysia
Tel: +601117899796
Fax: 006-044298007
E-mail: clinical.sunil@gmail.com

Received: September 25, 2017

Accepted: November 1, 2017

Published: November 8, 2017

Citation: Prajapati SK, Ali AN, Iqbal MZ, Mohanananaidu K, Mei LL, Ningzee C. Health Status of Students in a Private University in Malaysia. Madridge J Pharm Res. 2017; 1(1): 27-32.

doi: 10.18689/mjpr-1000105

Copyright: ( $\odot 2017$ The Author(s). This work is licensed under a Creative Commons Attribution 4.0 International License, which permits unrestricted use, distribution, and reproduction in any medium, provided the original work is properly cited.

Published by Madridge Publishers

\begin{abstract}
University students all over the globe are commonly affected by various health problems that impact their academic and daily life. Common illnesses like flu, cough, stress, anxiety, and depression deteriorates their well-being, leading to interference with their university experiences and learning process. This study aims to investigate the occurrence of common illnesses in students of a private university of Malaysia that affects their health and quality of life.
\end{abstract}

Method: A cross-sectional study was carried out among 400 students by convenience sampling from all faculties of a private university. A descriptive analysis was carry-out using SPSS (Version 20) for estimating various illnesses reported on pre-validated General Health Assessment form.

Result: Occurrence of common illnesses among university students during the previous 12 months was estimated and the same was also compared tothe previous month. The study found significant correlation ( $p=0.01$ ) in most of the illnesses studied. The overall study shows that the health of students surveyed is under the acceptable rang. 5 students (1.3\%) stated that their general health was poor, 42 students (10.5\%) stated that their general health was fair, 191 students (47.8\%) stated that their general health was good, 101 students $(25.3 \%)$ stated that their general health was very good and 61 students (15.3\%) stated that their general health was excellent on the Likert scale.

Conclusion: This cross sectional study indicates that despite students being exposed to several stress factors that lead them to being more prone to illnesses or poor healthy state such as mental, environmental and academic stress, most of the students of university were healthy. Their health status was still in the scale of excellent or very good.

Keywords: Student health; University students; Common illness; Health assessment questionnaire.

\section{Introduction}

University experience is of great value in providing emerging adults with a structured environment in building their knowledge, social and verbal skills, cognitive function, and their ability in decision-making. The potential obstacle to maximizing success in university is the high prevalence of occurring health conditions amongst the students. Research shows that at least 3 times a week, $60 \%$ of students have reported that they felt like dragging, tired, or sleepy [1]. The university years are a time of critical transition from adolescence to adulthood. The students having a prevalent health problem, no matter how minor it is, makes it difficult for them to focus on their everyday university life as these problems tend to interfere with concentration, problem-solving abilities, critical response, focus and overall performance leading to discomfort, moodiness and irritability [2]. Over the years, there were many studies that have been conducted to investigate and prove how seasonal allergies could cost bright students lower grades and impaired learning ability [3]. 
Malaysia has been experiencing erratic weather patterns of late, some of which have never before been witnessed before. As a country sitting close to the equator, Malaysia is accustomed to the consistency of a tropical climate. Temperatures generally average $27^{\circ} \mathrm{C}$ and humidity levels are typically at $70 \%$ to $90 \%$ [4]. However, in the past year it has experienced scorching heat reaching $41^{\circ} \mathrm{C}$, an unusual amount of rainfall during the monsoon season which resulted in severe flooding in several states, a typical cold weather such as recently experienced in Kelantan as well as increasing occurrences of mini tornadoes [5-7].

Numerous studies have been conducted to determine the impact of climate change throughout the world [8]. It leads to increase in the development of seasonal allergies and other health-related problems amongst students [9]. Insect bites in rural campuses, seasonal allergies, nausea, vomiting, and diarrhea almost always lead to discomfort, pain and the inability to focus in class. Missing out on classes eventually paves way to even more serious problems [10]. Students start falling behind on their schedule, assignments, projects, etc., inducing gradual stress development which paves way to even more prevalent issues faced i.e. sleeping difficulty. The conjunction of sleep difficulty brings insomnia, daytime sleepiness, irregular sleeping schedules and sleep deprivation [11]. Many diseases factors are analyzed on the basis of multiple factors that encourage the occurrence of these diseases in a private university during various seasons all year long. Although, Malaysia is situated in a tropical region, recent climate changes have brought in a drastic increase in temperatures and more aggressive monsoons [12]. These environment changes bring many new diseases if not aggravating existing disease conditions. This study is designed to establish the incidence of common illnesses of student studying in a private university since these illnesses/ diseases may affect the learning outcomes (Figure 1).

\section{Methodology}

\section{Population Studied}

The population, in which the investigative study was conducted, comprises of the students of various faculties. A total number of 3,642 students are studying in the university where this study was conducted. 400 students of the university were chosen to participate in the study. They were randomly selected from different enrolled programs, the number of years of pursuing the programs, race, gender and age. Sample size was calculated based on the Raosoft online software.

\section{Study design}

Cross sectional study was carried out for this research project. It is used to gather information about students' health. The objective of cross sectional studyin this project was to assess students' attitude and behavior to their health and practice of the university student. A Health Assessment questionnaire form was designed and validated to carry out cross sectional study.

\section{Instrumentation}

A questionnaire was developed by the investigators based on the available literature and expert opinions. The questionnaire was divided in 2 sections. In first section their demography of students was measured and second section their health status was recorded. Four Likert items (4 points scale -Not at all, rarely, occasionally and frequently) and seven Likert items (7 points scaled -Never, one time, two times, three times, four times, five times and more than five times) were designed to evaluate students' health status in the university. Close-ended questions were also designed to assess health status of students in the university.

\section{Ethical Considerations}

The research proposal along with the study instruments (questionnaire) and informed consent form was submitted to the same university's Human and Animal Ethical Committee and the ethical clearance were obtained before the study was conducted. Further, the informed consent form was used to confirm the willingness of the participants to take part in this survey study. The objectives of the survey and the purpose of monitoring health status of student in the university were also stated.

\section{Statistical Analysis}

The Statistical Package for the Social Science (SPSS) version 20 was used as the statistical software to analyze data obtained from questionnaire. Response percentage, mean and correlation between different responses were analyzed by using this software. Descriptive statistics and Pearson Coefficient of correlation test were used to analyze data and $p$ value $\leq 0.05$ was considered as significant. Pilot test was conducted among 20 students of the university. The reliability of the attitudes scale was assessed via Cronbach's Alpha measure (0.704).

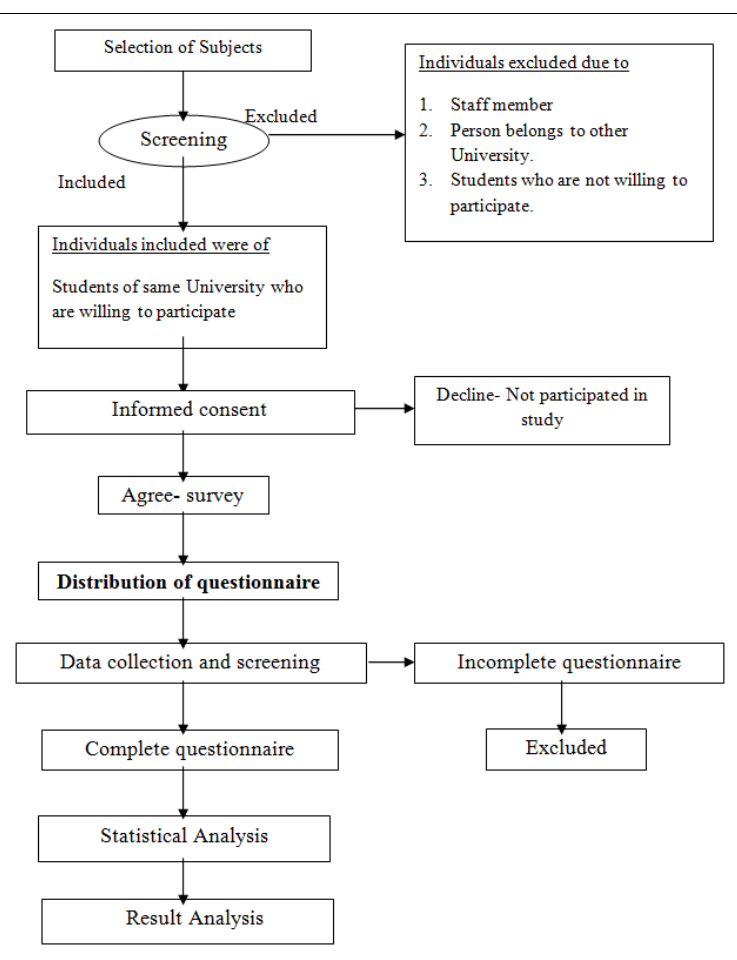

Figure 1. Schematic representation of flow chart of the study 


\section{Results}

\section{Sample Characteristics}

400 subjects of a private university participated in the study, including 125 males (31.3\%) and 275 females (68.7\%). The mean and standard deviation of 400 students are 21.49 and 1.741 respectively. Of these 400 students, 306 students were hosteller whereas 94 of them were day-scholar.

They were 89 students (22.3\%) from Pharmacy, 71 students (17.8\%) from Medicine,72 students (18.0\%) from Dentistry, 13 students (3.3\%) from Engineering, 75 students (18.8 \%) from Foundation Studies, 18 students (4.5\%) from Physiotherapy, 34 students (8.5\%) from Biotechnology, 16 students (4.0\%) from Business and Management, and 12 students (3.0\%) from Nursing department. There were 132 first year students (33.0\%), 89 second year students (22.3\%), 100 third year students (25.0\%), 49 fourth year students (12.3\%), and 30 firth year students (7.5 $\%)$ in this study. The racial breakdown of respondents involved in the study were 17 Malay (4.3\%), 257 Chinese (64.3\%), 108 Indian (27.0\%), and 18 respondents (4.5\%) from other races.

\section{Incidence of common illnesses in past 12 months}

With the inclusion of all the factors contributing to stress such as climate, environment, academic load, this study showed that the commonest illness reported was fever. $25.8 \%$ of students suffered fever at least once in the last 12 months. The second common illness was cold. $24.3 \%$ of students suffered from cold at least once in the last 12 months. The third common illness suffered by students was cough with $23.5 \%$ of students having had a cough 'more than five times' in past 12 months. This study also found that $26 \%$ of students 'never suffered' from cough in past 12 months, while they may have other illnesses. The study revealed that $92.5 \%, 89.3 \%$ and 86.3 of students did not suffer from uncommon health related problems such as urinary tract infection, ear infection and eye infection respectively. Common illnesses suffered by students in the past 12 months are tabulated in table 1.

Table 1. Incidence of common illnesses in past 12 months

\begin{tabular}{|l|l|l|l|l|l|l|l|}
\hline $\begin{array}{l}\text { Illness in past 12 } \\
\text { months(n=400) }\end{array}$ & $\begin{array}{l}\text { Never } \\
\text { suffered } \\
(\%)\end{array}$ & $\begin{array}{l}\text { One } \\
\text { time } \\
(\%)\end{array}$ & $\begin{array}{l}\text { Two } \\
\text { times } \\
(\%)\end{array}$ & $\begin{array}{l}\text { Three } \\
\text { times } \\
(\%)\end{array}$ & $\begin{array}{l}\text { Four } \\
\text { times } \\
(\%)\end{array}$ & $\begin{array}{l}\text { Five } \\
\text { times } \\
(\%)\end{array}$ & $\begin{array}{l}\text { More than } \\
\text { five times } \\
(\%)\end{array}$ \\
\hline Cold & 28.3 & 24.3 & 17.8 & 14.8 & 2.5 & 2.8 & 9.3 \\
\hline Cough & 26.0 & 23.5 & 22.8 & 14.3 & 4.3 & 1.5 & 7.8 \\
\hline Diarrhea & 40.3 & 19.8 & 13.8 & 10.5 & 2.3 & 2.5 & 11.0 \\
\hline Dysmenorrhea & 81.5 & 7.5 & 4.8 & 1.8 & 0.3 & 0.5 & 3.8 \\
\hline Ear infection & 89.3 & 6.3 & 2.5 & 1.0 & 0.0 & 0.0 & 1.0 \\
\hline Eye infection & 86.3 & 7.5 & 3.3 & 1.3 & 0.5 & 0.5 & 0.8 \\
\hline Oral Health & 76.8 & 12.3 & 6.8 & 1.5 & 1.0 & 0.3 & 1.5 \\
\hline Fever & 35.5 & 25.8 & 21.5 & 9.3 & 3.3 & 0.8 & 4.0 \\
\hline Flu & 27.5 & 22.3 & 22.5 & 12.0 & 5.0 & 2.0 & 8.8 \\
\hline Gastritis & 67.3 & 13.5 & 6.5 & 4.5 & 2.3 & 0.8 & 5.3 \\
\hline Headache & 28.0 & 18.5 & 14.3 & 13.0 & 6.3 & 2.0 & 18.0 \\
\hline Insect bite & 48.3 & 17.8 & 10.8 & 7.8 & 2.0 & 1.5 & 12.0 \\
\hline Nausea & 75.3 & 7.0 & 7.0 & 3.8 & 0.8 & 1.5 & 4.8 \\
\hline Physical injury & 60.8 & 13.5 & 11.0 & 6.3 & 2.8 & 0.8 & 5.0 \\
\hline Skin infection & 76.3 & 10.5 & 5.5 & 4.0 & 0.5 & 0.5 & 2.8 \\
\hline Sore throat & 36.5 & 20.0 & 20.5 & 11.0 & 4.8 & 1.5 & 5.8 \\
\hline $\begin{array}{l}\text { Urinary Tract } \\
\text { Infection }\end{array}$ & 92.5 & 3.3 & 1.8 & 1.0 & 0.5 & 0.0 & 1.0 \\
\hline Vomiting & 72.0 & 14.3 & 6.3 & 3.0 & 1.3 & 0.3 & 3.0 \\
\hline Others & 94.3 & 3.0 & 0.8 & 1.0 & 0.3 & 0.0 & 0.8 \\
\hline Average & 60.14 & 14.24 & 10.54 & 6.41 & 2.14 & 1.04 & 5.60 \\
\hline
\end{tabular}

On average, $60.14 \%$ of students reported that they did not suffer from any illness. $14.24 \%$ of students' suffered from illnesses at least 'one time' in past 12 months, $10.54 \%$ of students 'two times' in past 12 months, $6.41 \%$ of students suffered from various illnesses three times in past 12 months, 2.14\% students suffered from illness 'four times' in past 12 months, $1.04 \%$ of students suffered from illness 'five times' in 12 months, and lastly $5.6 \%$ of students suffered from illness 'more than five times' on 7 point Likert scale in last 12 months of study.

\section{Incidence of Pain in the past one month}

The survey indicated that $2.5 \%$ of the total population $(n=400)$ experienced pain which interfered with their studies frequently, $17.5 \%$ of them reported that they experienced pain which interfered their studies occasionally, $46.8 \%$ of them showed pain interference with their studies rarely and $33.3 \%$ of them never experience pain interference in their studies as mentioned in figure 2.

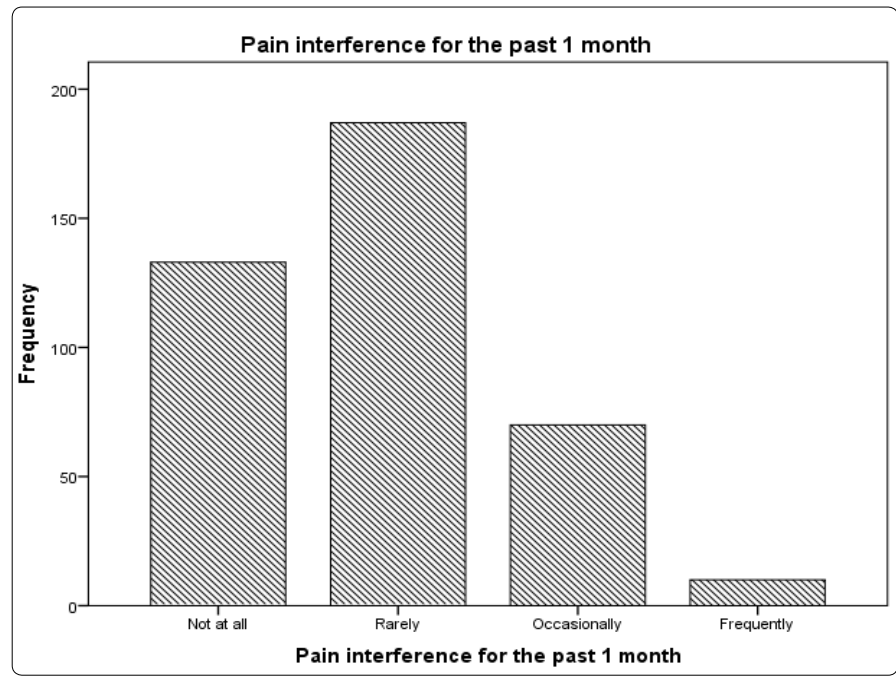

Figure 2. Incidence of Pain in the past one month

A closed ended question was also designed for find out the frequency of medical consultation by the students. The results found that $60.3 \%$ of students had gone for medical consultation while remaining $39.8 \%$ had not gone for any medical consultation in past one month for their pain management.

\section{Incidence of common illnesses in past one month}

In past one month, the first common illness reportedwasflu, $28 \%$ of students suffered on 'one time' 7 point Likert scale. The second common illness reported was headache, $15.8 \%$ of students suffered 'two times' in last one month on Likert scale as mentioned in table 2.

The other common illness suffered by students was insect bite. $5.5 \%$ of students stated that they suffered insect bite 'more than five times'on Likert scale in past one month.The uncommon health related problems like ear infection and eye infection were reported has'never been experienced by $92.8 \%$ and $91 \%$ of students respectively. $96 \%$ Students did not suffer from diseases like urinary tract infection in the past one month. Apart from above stated illnesses, $96.8 \%$ of students noted that they did not suffer during the past one month from those illnesses as stated in table 2. 
Table No 2. Incidence of common illnesses in past 12 months

\begin{tabular}{|l|l|l|l|l|l|l|l|}
\hline $\begin{array}{l}\text { Illness in past one } \\
\text { month(n=400) }\end{array}$ & $\begin{array}{l}\text { Never } \\
\text { suffered } \\
(\%)\end{array}$ & $\begin{array}{l}\text { One } \\
\text { time } \\
(\%)\end{array}$ & $\begin{array}{l}\text { Two } \\
\text { times } \\
(\%)\end{array}$ & $\begin{array}{l}\text { Three } \\
\text { times } \\
(\%)\end{array}$ & $\begin{array}{l}\text { Four } \\
\text { times } \\
(\%)\end{array}$ & $\begin{array}{l}\text { Five } \\
\text { times } \\
(\%)\end{array}$ & $\begin{array}{l}\text { More than } \\
\text { five times } \\
(\%)\end{array}$ \\
\hline Cold & 59.0 & 24.3 & 8.3 & 4.5 & 0.5 & 1.0 & 2.5 \\
\hline Cough & 59.0 & 24.5 & 9.3 & 3.8 & 0.5 & 1.3 & 1.8 \\
\hline Diarrhea & 61.3 & 19.0 & 9.0 & 5.8 & 1.3 & 1.0 & 2.8 \\
\hline Dysmenorrhea & 89.5 & 6.3 & 2.5 & 1.3 & 0.0 & 0.3 & 2.8 \\
\hline Ear infection & 92.8 & 4.3 & 1.0 & 0.8 & 0.8 & 0.0 & 0.5 \\
\hline Eye infection & 91.0 & 5.5 & 1.3 & 1.5 & 0.3 & 0.0 & 0.5 \\
\hline Fever & 70.3 & 21.0 & 0.5 & 1.5 & 0.8 & 0.5 & 1.0 \\
\hline Flu & 56.5 & 28.0 & 6.3 & 5.5 & 0.5 & 0.8 & 2.5 \\
\hline Gastritis & 76.8 & 10.3 & 5.5 & 4.0 & 1.0 & 1.8 & 0.8 \\
\hline Headache & 42.5 & 23.3 & 15.8 & 8.0 & 4.0 & 1.3 & 5.3 \\
\hline Insect bite & 61.5 & 13.3 & 10.3 & 6.5 & 2.5 & 0.5 & 5.5 \\
\hline Nausea & 79.0 & 9.3 & 6.0 & 3.5 & 0.8 & 0.5 & 1.0 \\
\hline Physical injury & 69.5 & 16.0 & 7.8 & 4.5 & 0.8 & 0.3 & 1.3 \\
\hline Skin infection & 82.0 & 11.0 & 4.5 & 2.0 & 0.3 & 0.0 & 0.3 \\
\hline Sore throat & 58.5 & 24.0 & 10.8 & 4.5 & 0.8 & 0.5 & 1.0 \\
\hline Urinary Tract & 96.0 & 2.0 & 0.8 & 0.5 & 0.0 & 0.0 & 0.8 \\
\hline Infection & 89.3 & 5.8 & 2.0 & 1.5 & 0.3 & 0.3 & 1.0 \\
\hline Vomiting & 96.8 & 1.3 & 0.5 & 0.5 & 0.3 & 0.0 & 0.8 \\
\hline Others & 73.96 & 13.84 & 5.677 & 3.34 & 0.86 & 0.56 & 1.78 \\
\hline Average & & & & & \\
\hline
\end{tabular}

On average, illnesses reported as 'never suffered' by $73.96 \%$ of students, $13.84 \%$ of students' suffered from illness 'one time' in last one month, $5.67 \%$ of students suffered from illness 'two times' in last one month, 3.34\% of students suffered from illness 'three times' in last one month, $0.86 \%$ students suffered from illness 'four times' in last one month, $0.56 \%$ of students suffered from illness 'five times' in last one month, and lastly $1.78 \%$ of students suffered from illness 'more than five times' in last one month of study. So the study depicts that most of the students were not suffering from serious illnesses or major diseases shown in table 2.

\section{Correlation on illnesses in the past one month and illnesses in the past 12 months}

From Pearson bivariate correlation analysis, this study found that students suffering from cold in the past one month has a correlation with cold being suffered in past 12 months $(r=0.60, p=0.01)$, for cough $(r=0.527, p=0.01)$, for diarrhea $(r=0.691, p=0.01)$, for dysmenorrhea $(r=0.609, p=0.01)$, for ear infection $(r=0.718, p=0.01)$, for eye infection $(r=0.534, p=0.01)$, for fever $(r=0.507, p=0.01)$, for flu $(r=0.599, p=0.01)$, for gastritis $(r=0.680, p=0.01)$, for headache $(r=0.630, p=0.01)$, for insect bite $(r=0.668, p=0.01)$, for nausea $(r=0.693, p=0.001)$, for physical injury $(r=0.410, p=0.01)$, for skin infection $(r=0.582, p=0.01)$, for sore throat $(r=0.543, p=0.01)$, for urinary tract infection $(r=0.558, p=0.01)$, for vomiting $(r=0.587$, $p=0.01)$, and for other illnesses $(r=0.825, p=0.01)$. The data indicates that illnesses for past one month and past 12 months were correlated on many aspects of health except physical injuries.

\section{Mental and emotional health status}

The investigated parameters of mental and emotional health status of students revealed that $55.5 \%$ and $16.8 \%$ of the students felt energetic 'occasionally' and 'frequently' respectively during the past one month; $43.3 \%$ of the students had the feeling of nervousness'occasionally'and $43.5 \%$ of them felt down hearted 'rarely'. 75.5\% of participants reported feeling calm and peaceful either 'frequently' or 'occasionally'. Furthermore, $41.3 \%$ of students reported to feeling exhausted 'occasionally', $47.8 \%$ of them felt happy 'occasionally', $30.8 \%$ of the students 'never' face any difficulty in sleeping while $32.3 \%$ of them felt difficulty in sleeping 'rarely' [13]. These results are tabulated in table 4.

Table 4. Mental and emotional health status of students.

\begin{tabular}{|l|l|l|l|l|}
\hline Question & $\begin{array}{l}\text { Not at } \\
\text { all (\%) }\end{array}$ & $\begin{array}{l}\text { Rarely } \\
(\%)\end{array}$ & $\begin{array}{l}\text { Occasionally } \\
(\%)\end{array}$ & $\begin{array}{l}\text { Frequently } \\
(\%)\end{array}$ \\
\hline 4. Did you feel full of energy? & 7.8 & 20.0 & 55.5 & 16.8 \\
\hline 5. Have you been feeling nervous? & 10.5 & 37.5 & 43.3 & 8.8 \\
\hline $\begin{array}{l}\text { 6. Have you felt so down in the dumps } \\
\text { that nothing could cheer you up? }\end{array}$ & 21.0 & 44.3 & 28.0 & 6.8 \\
\hline 7. Have you felt calm and peaceful? & 7.3 & 17.3 & 51.0 & 24.5 \\
\hline 8. Have you felt downhearted? & 19.8 & 43.5 & 30.8 & 6.0 \\
\hline 9. Did you feel exhausted? & 11.5 & 32.0 & 41.3 & 15.3 \\
\hline 10. Have you been feeling happy? & 5.0 & 12.3 & 47.8 & 35.0 \\
\hline 11. Did you feel difficulty in sleeping? & 30.8 & 32.3 & 27.8 & 9.3 \\
\hline
\end{tabular}

Health issues hampering students'participating in the learning process and other activities in the past 12 months

$1.8 \%$ students suffered 'frequent' difficulty in their learning process and in participating in various activities of the university, $14.3 \%$ students reported to have 'occasional' difficulty, $41.3 \%$ of them reported that they had 'rare' difficulty while majority of the students, $42.8 \%$ reported having 'Not at all' difficulty in participating in various activities based on the health assessment form (Table No. 5).

Table 5. Incidences of health issues among students

\begin{tabular}{|l|l|l|}
\hline Health issue & Frequency $(\mathbf{n = 4 0 0 )}$ & Percentage (\%) \\
\hline Not at all & 171 & 42.8 \\
\hline Rarely & 165 & 41.3 \\
\hline Occasionally & 57 & 14.3 \\
\hline Frequently & 7 & 1.8 \\
\hline
\end{tabular}

\section{Discussion}

This study was conducted to determine the students' health abnormality experienced in a private university in relation to their habits, lifestyles, medications, climate and other factors that affect their health status and how it affects their daily activities. The study findings showed that the minimum age of students was 17 years old while the maximum age of students was 28 years old with mean of 21.39 years.

The study results showed that $88.2 \%$ of students reported to be in excellent, very good or good health while $11.8 \%$ of them reported to be in either fair or poor health on Likert scale. Based on the findings, better health status of students can be achieved by controlled behavior, nutrition and lifestyle [14]. Based on our study, we believe that most of the students of this university had maintained balanced diet and healthy lifestyles [15].

Health issues were reported with similar patterns of illnesses in both genders [16]. 92\% of all males reported having either 'excellent', 'very good' or 'good' health while only $8 \%$ of all males reported having either 'fair' or 'poor health' and $86.5 \%$ of female respondents reported having 'excellent', 'very good' or 'good' health while $13.5 \%$ of all 
females reported having either 'fair or poor health'. From the point of view of gender, females tend to have slightly higher percentage of 'fair or poor health' status. Females reported that their health status abnormality was due to irregular menstrual cycle and it could be related to diet consciousness [17].

We found about $88.2 \%$ of all races report to be in 'good' or 'better' health and $11.8 \%$ for 'fair' or 'poor' good health. This shows that all races in this university had similar pattern of illnesses on general health assessment scale. Racial difference is not associated with self-reported health status [18]. According to years of study in a particular program, first year students of all programs reported higher stress levels. Fourth year students of all programs reported to be in good health. However, there were no significant differences among the number of years of pursuing the programs. Rather, first year students need social and family support to improve their psychological stress status [19]. Medical students were found to be more stressful than students in other programs. The levels of stress rated at mild, moderate and high [20]. The most experienced physical illnesses experienced in the past one month was insect bite (5.5\%), headache (5.3\%), diarrhea and dysmenorrhea (2.8\%), common cold and flu by $2.5 \%$ of students. This study did not reveal any serious illness which needed further attention [21-24].

Considering Likert scale of 'more than five times 'domain, this study results showed that the illness most experienced in past 12 months was headache (18\%), and may be stress induced [25]. The Second common problem is insect bite (12\%) which may due to the rural setting of university [26]. The third most illness encountered was diarrhea $(11 \%)$ which may be due to unhygienic food being served in the university or due to poor hygiene by the students. The fourth common illness was cold (9.3) and fifth was cough (7.8) which may occurs due to change in atmosphere $\&$ whether [27-29]. The incidence of insect bite can be due to various factors such as environmental factors and host factors [30]. Environmental factors include the topical setting, spending time in the garden, overcrowding and poor hygiene and student accommodation environment are main factors insect bite. However, various methods of preventing insect bite can be taken to reduce the occurrence. Various methods include protective clothing, insecticide sprays, residential insecticides, repellents or physical means by using nets are be considered as precautions of insect bite.

On the average illness occurred $5.6 \%$ in past 12 month on 'more than five times' domain, while illness occurred on average $1.78 \%$ in past one month on 'more than five times' domain. In summary the illness most experienced by students in the past 12 months and one month were diarrhea and cold. Further research is needed to investigate factors contributing to these illnesses. Headache and insect bite could be environmental and can be controlled with the help simple measures.

In summarizing the health status of students, most of them experienced cold, headache, gastritis, insect bite, diarrhea and nausea in past one month and past 12 months.
According to some studies, stress is related to the health and illness [31]. A person who has been exposure to a continuous stressful environment easily gets illness. The function of immune system in the body may decline with prolonged stress. In some studies, stress was also found to induce the release of glucocorticoids in the brain. These steroid hormones bring negative influence on hippocampus in long term condition. It can cause damage to memory function [32]. In this case, students are mostly exposure to the continuous stressful environment due to their busy schedule. This could be related to majority of them suffering from illnesses such as cold and headache [33].

In the aspect of mental and emotional health, the study showed that the majority of the students did not have the feeling of being dumped. Most of them felt full of energy and they did not have the feeling of nervousness.

The study also shows that some of the students were having difficulty in sleeping, i.e. insomnia [34]. 2.5\% of the total study population $(n=400)$ reported that they experienced pain interference with their studies 'frequently'. Some studies found that pain and stress are co-related.

The study results regarding medical consultation show that $60.3 \%$ of students had gone to clinics or hospital for while remaining $39.8 \%$ had never gone for any medical consultation $[35,36]$.

From Pearson bivariate correlation analysis, it was found that illnesses in past one month have a correlation with various illnesses in past 12 months. This indicates that incidences of various health problems are associated with past one month and past 12 months. Therefore, the study'sfinding of annual incidence of various health issues is usually happens around the year in this university.

\section{Conclusion}

The students tend to suffer from certain common illnesses like insect bite, headache, diarrhea, dysmenorrhea, cold, flu and cough and this affect their health status which may lead to poor quality of life. However, these incidences contributed only in a small percentage of the student population under study. Dysmenorrhea symptoms such as abdominal cramps due to painful menstruation were suffered by females. However, Urinary tract infections (UTI), ear infections and eye infections are also found as rare illnesses with the low percentage of prevalence. With reference to mental health, overall the emotional, psychological and social well-beingwere found to be in the acceptable rang for healthy learning process. The students of the university felt happy, calm and peaceful 'frequently'. In a nut shell, students from this university were in the healthy state in both aspects of physical and mental health.

\section{Acknowledgements}

We would like to express mykind gratitude to all of the participating students and faculties for their time, cooperation, supportand patience given during the data collection exercise. 


\section{References}

1. Curcio G, Ferrara M, De-Gennaro L. Sleep loss, learning capacity and academic performance. Sleep medicine reviews. 2006; 10(5): 323-337. doi: 10.1016/j.smrv.2005.11.001

2. Buboltz WC, Brown F, Soper B. Sleep habits and patterns of college students: a preliminary study. Journal of American college health. 2001; 50(3): 131-135. doi: 10.1080/07448480109596017

3. Chung KF, Chen EY, Liu CS. University students' attitudes towards mental patients and psychiatric treatment. International Journal of Social Psychiatry. 20011; 47(2): 63-72. doi: 10.1177/002076400104700206

4. Ancis JR, Sedlacek WE, Mohr JJ. Student perceptions of campus cultural climate by race. Journal of Counseling \& Development. 2000; 78(2): 180185. doi: 10.1002/j.1556.26676.2000.tb02576.x

5. Zain ZM, Taib MN, Baki SMS. Hot and humid climate: prospect for thermal comfort in residential building. Desalination. 2007; 209(1-3): 261-268. doi: 10.1016/j.desal.2007.04.036

6. Loo YY, Billa L, Singh A. Effect of climate change on seasonal monsoon in Asia and its impact on the variability of monsoon rainfall in Southeast Asia. Geoscience Frontiers. 2015; 6(6): 817-823. doi: 10.1016/j.gsf.2014.02.009

7. Noguchi S, Nik AR, Sammori T, Tani M, Tsuboyama Y. Rainfall characteristics of tropical rain forest and temperate forest: comparison between Bukit Tarek in Peninsular Malaysia and Hitachi Ohta in Japan. Journal of Tropical Forest Science. 1996; 206-220.

8. Ibrahim K, Shabudin AFA, Koshy CK, Asrar GR. A new framework for integrated climate finance and inclusive responses to sustainable development in Malaysia. Geomatics, Natural Hazards and Risk. 2016; 7(6): 1754-1768. doi: 10.1080/19475705.2016.1155503

9. Parry ML, Rosenzweig $C$, Iglesias $A$, Livermore $M$, Fischer $G$. Effects of climate change on global food production under SRES emissions and socio-economic scenarios. Global Environmental Change. 2004; 14(1): 5367. doi: 10.1016/j.gloenvcha.2003.10.1008

10. Hagy GW, Settipane GA. Bronchial asthma, allergic rhinitis, and allergy skin tests among college students. Journal of Allergy. 1969; 44(6): 323-332. doi: 10.1016/0021-8707(69)90024-0

11. Intachat J, Holloway JD, Staines H. Effects of weather and phenology on the abundance and diversity of geometroid moths in a natural Malaysian tropical rain forest. Journal of Tropical Ecology. 2001; 17(3): 411-429. doi: $10.1017 /$ S0266467401001286

12. Brown FC, Buboltz WC, Soper B. Relationship of sleep hygiene awareness, sleep hygiene practices, and sleep quality in university students. Behavioral medicine. 2002; 28(1): 33-38. doi: 10.1080/08964280209596396

13. Tangang FT, Juneng $L$, Salimun $E$, et al. Climate change and variability over Malaysia: gaps in science and research information. SainsMalaysiana. 2012; 41(11): 1355-1366.

14. Symons CW, Cinelli B, James TC, Groff P. Bridging student health risks and academic achievement through comprehensive school health programs. Journalofschool Health. 1997;67(6):220-227.doi:10.1111/j.1746-1561.1997. tb06309.x

15. Trovato GM. Behavior, nutrition and lifestyle in a comprehensive health and disease paradigm: skills and knowledge for a predictive, preventive and personalized medicine. EPMA J. 2012; 3(1): 8. doi: 10.1007/s13167012-0141-2

16. Wardle J, Haase AM, Stepto A. Body image and weight control in young adults: international comparisons in university students from 22 countries. International journal of obesity. 2006; 30(4): 644. doi: 10.1038/sj.ijo.0803050

17. Bayram N, Bilgel N. The prevalence and socio-demographic correlations of depression, anxiety and stress among a group of university students. Social psychiatry and psychiatric epidemiology. 2008; 43(8): 667-672. doi: 10.1007/ s00127-008-0345-x
18. Williams DR, Mohammed SA. Discrimination and racial disparities in health: evidence and needed research. Journal of behavioral medicine. 2009; 32(1): 20-47. doi: 10.1007/s10865-008-9185-0

19. Friedlander L, Reid GJ, Shupak N, Cribbie R. Social support, self-esteem, and stress as predictors of adjustment to university among first-year undergraduates. Journal of college student development. 2007; 48(3): 259274.

20. Moffat K, McConnachie A, Ross S, Morrison JM. First year medical student stress and coping in a problem-based learning medical curriculum. Medical education. 2004; 38(5): 482-491. doi: 10.1046/j.1365-2929.2004.01814.x

21. Deleu D, Khan MA, Humaidan $\mathrm{H}, \mathrm{Al}$-Mantheri Z, Al Hashami S. Prevalence and clinical characteristics of headache in medical students in Oman. Headache: The Journal of Head and Face Pain. 2001; 41(8): 798-804. doi: 10.1046/j.1526-4610.2001.01146.x

22. Unsal A, Ayranci U, Tozun M, Arslan G, Calik E. Prevalence of dysmenorrhea and its effect on quality of life among a group of female university students. Upsala journal of medical sciences. 2012; 115(2): 138-145. doi: 10.3109/03009730903457218

23. Cakir M, Mungan I, Karakas T, Girisken I, Okten A. Menstrual pattern and common menstrual disorders among university students in Turkey. Pediatrics International. 2007; 49(6), 938-942. doi: 10.1111/j.1442-200X.2007.02489.x

24. Phillips CA, Riggs $S$, Melnick JL, Grim CA. Rhinoviruses associated with common colds in a student population. Jama. 1965; 192(4): 277-280. doi: 10.1001/jama.1965.03080170005001

25. Ojini Fl, Okubadejo NU, Danesi MA. Prevalence and clinical characteristics of headache in medical students of the University of Lagos, Nigeria. Cephalalgia, 2009; 29(4): 472-477. doi: 10.1111/j.1468-2982.2008.01766.x

26. Khun S, Manderson L. Community and school-based health education for dengue control in rural Cambodia: a process evaluation. PLoS neglected tropical diseases. 2007; 1(3): 143. doi: 10.1371/journal.pntd.0000143

27. Morrone $M$, Rathbun A. Health education and food safety behavior in the university setting. Journal of Environmental Health. 2003; 65(7): 9.

28. Braden CR. Infectiousness of a university student with laryngeal and cavitary tuberculosis. Clinical Infectious Diseases. 1995; 21(3): 565-570.

29. Dusselier L, Dunn B, Wang Y, Shelley MC, Whalen DF. Personal, health, academic, and environmental predictors of stress for residence hall students. Journal of American college health. 2005; 54(1): 15-24. doi: 10.3200/JACH.54.1.15-24

30. Abdel-Hafez K, Abdel-Aty MA, Hofny ER. Prevalence of skin diseases in rural areas of Assiut Governorate, Upper Egypt. International journal of dermatology.2003;42(11):887-892. doi:10.1046/j.1365-4362.2003.01936.x

31. Thoma, JJ, Borrayo EA. The Combined Influence of Psychosocial Factors on Illness Behavior Among Women. Women \& health. 2014; 54(6): 530551. doi: 10.1080/03630242.2014.903886

32. Sauro MD, Jorgensen RS, Pedlow CT. Stress, glucocorticoids, and memory: a meta-analytic review. Stress. 2003; 6(4): 235-245. doi: $10.1080 / 10253890310001616482$

33. Thorn $B E$, Pence $L B$, Ward $L C$, et al. A randomized clinical trial of targeted cognitive behavioral treatment to reduce catastrophizing in chronic headache sufferers. The Journal of Pain. 2007; 8(12): 938-949. doi: 10.1016/j.jpain.2007.06.010

34. Wortzman RL. Mental health promotion as a prevention and healing tool for issues of youth suicide in Canadian Aboriginal communities. First Peoples Child \& Family Review. 2009; 4(1): 20-27.

35. Abay SM, Amelo W. Assessment of Self-medication practices among medical, pharmacy, health science students in Gondar University, Ethiopia. Journal of Young Pharmacists. 2010; 2(3): 306-310. doi: 10.4103/09751483.66798

36. Lau GS, Lee KK, Luk MC. Self-medication among university students in Hong Kong. Asia Pacific Journal of Public Health. 1995; 8(3): 153-157. 